\title{
バクテリアの細胞表面と熱ストレス傷害，熱耐性
}

\author{
土 户哲 明 \\ 関西大学工学部生物工学科 㦁 564-8680 大阪府吹田市山手町 3-3-35
}

(2001 年 5 月 14 日受理)

\section{Bacterial Cell Surface and Its Damage by Heat in Relation to Cellular Heat Resistance}

\author{
Tetsuaki TsucHIDO \\ Faculty of Engineering, Kansai University \\ 3-3-35 Yamate-cho, Suita, Osaka 564-8680 \\ (Received May 14, 2001)
}

\begin{abstract}
The cell surface changes sensitively with environmental stimuli because it locates at the interface between the cell and the environment. Bacteria have their elaborate systems against a variety of stresses as well as other organisms and possess abilities to adapt to, recover from, or obtain tolerance for stressful situations. In some cases, damages to the cell surface are likely to cause directly cell death. Here, an outline of our studies on the effect of heat stress on the structure and functions of cell surface and on the role of cell surface with regard to the heat resistance of bacteria is described.
\end{abstract}

\section{1.は じめに}

微生物には , 人間の生活に有用なものもあれば有害な ものも数多い。光れらは人体に入って病気を引き起こし， ときには光れがもとで死に至らしめることもあれば，衣 食住において腐敗や不快な環境を生じることもある。こ れら有害微生物を抑制するため, 人類は昔から熱や薬剂 を殺菌や静菌の主な手段として用いてきた。

このような殺菌・静菌処理は, 微生物を光れ光れ致死 的および非致死的ストレスにさらすことと言える。最近， 分子生物学や生理学の分野で, 微生物の各種物理的ある いは化学的ストレスに対する応答の研究が活発化してき ており, とくに細胞膜を中心とする細胞表面の構造, 機 能が光れら細胞のストレス耐性に影響を及ぼし，ひいて は光れら処理の殺菌, 静菌効果を左右することがわかっ てきている。

本稿では, 微生物の代表としてバクテリア (細菌) を とりあげ, 兴の表面構造を概観した後, 著者らがこれま で検討してきた，半致死的あるいは致死的な加熱ストレ

E-mail: ttsuchi@ipcku.kansai-u.ac.jp
スにさらした大腸菌細胞表面の損傷と修復 , また細胞の 熱耐性における产の表面の係わりについて紹介する。な お，この内容の多くは他の拙著 ${ }^{(2)} に も$ 述べているので， 参照されたい。

\section{2. バクテリア表面の構造と機能}

バクテリアの表面はどのような構造をしていて , どの ような機能をもっているのか, まずこれらのアウトライ ンを述べよう2,5)。

細胞の最も外側には細胞壁があるが , この構造の違い によってバクテリアは大きく 2 種類に分けられる。この 違いはグラム染色法によって見分けられる。この方法に よって染色されるグループはグラム陽性バクテリア (枯 草菌や黄色ブドウ状球菌などが含まれる), 染まらない 方はグラム陰性バクテリア (大腸菌や緑膿菌などが含ま れる) とよばれる (Fig. 1)。

細胞の形状を保つ役割をしているのがペプチド架橋を もつ多糖類であるムレインとよばれるぺプチドグリカン のメッシュ状のかたい層である。これによって細胞内部 の高い浸透圧による破裂から身を守っている。グラム陽 性バクテリアはこのムレインがラ゙厚く頑丈であり，概し 


\section{Gram-positive}

Gram-negative

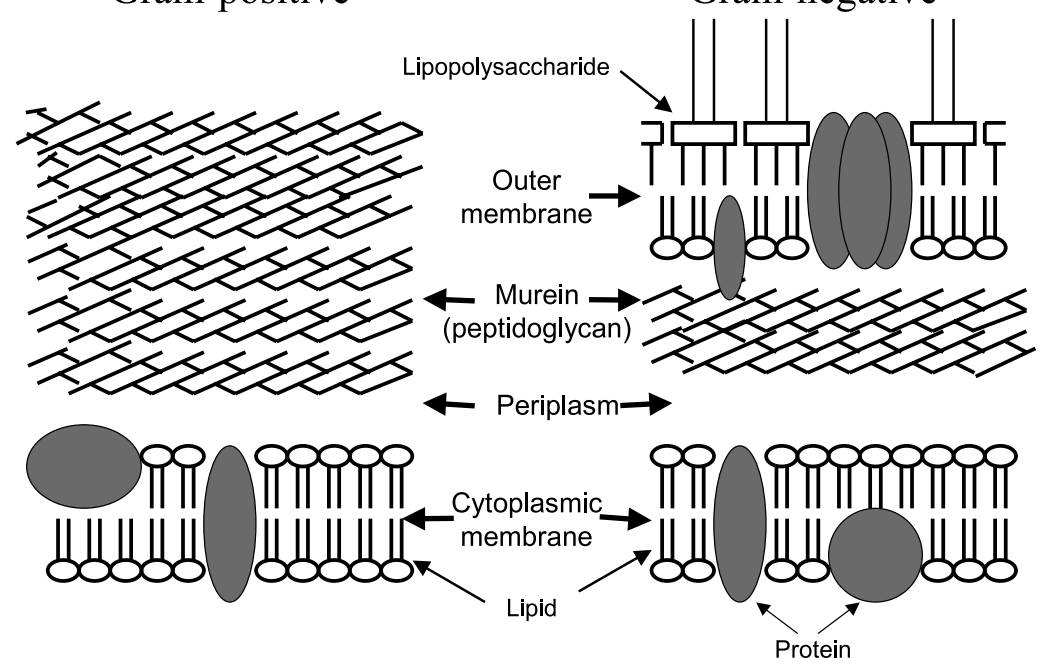

Fig. 1 Schematic representations of cell surface structures of gram-positive and gramnegative bacteria.

て熱や放射線などの物理的ストレスに強い。一方，グラ ム陰性バクテリアは, ムレイン層が比較的薄く, 弚のか わりに外側にリポ多糖体を含む外膜構造をもつことが特 徵で, 外界からの疎水性の抗生物質や食品防腐剂などに 対する透過障壁として機能している。このため, グラム 陰性バクテリアはおおざっぱに言って化学的ストレスに 強い。

細胞壁の内側には外界との仕切りとして, 脂質（ほと んどがグリセロリン脂質) の 2 重層構造の中に膜タンパ ク質が内在あるいは結合している細胞質膜がある。これ ら膜タンパク質には, 栄養基質の輸送タンパク質, 酸素 呼吸のための電子伝達系, 弚れに共役したエネルギー变 換を担うプロトン-ATP アーゼなど多くの細胞膜酵素が ある(Fig. 2)。このほか , バクテリアの種類によっては , 萊膜や運動器官である鞭毛, 付着や接合に関係する線毛 をもつものがある。

バクテリア細胞の表面の構造成分（糖や脂質，局在イ オンなど）によって产の表面物性に特色が現れる。光の 重要なものは, 表面電荷, 表面踈水性である。これらは 静電的相互作用や疎水性相互作用を通して種 々の化合物 の透過 ·排出や生物 ・担体表面との接触・付着に関わっ てくる。また , 細胞壁の内側にある細胞質膜には上述の ようにさまざまな膜酵素があるが, 弚れらの機能は膜脂 質の流動性の影響を強く受ける。

Fig. 3 は凍結割断法によって作成された大腸菌細胞表 面の電子顕微鏡像である゙)。表面の粒々 (膜内粒子) が 細胞膜を貫通している膜タンパク質と考えられ，これら
のタンパク質の機能や安定性は周囲の脂質の相, すなわ ち液晶状態かゲル状態かによって変化する。この图に示

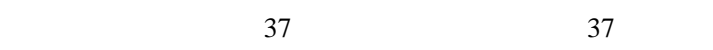
いたときには, これら膜内粒子は均一分散しており，こ れは, このときの膜が夜晶相であるためである。しかし， この細胞を $0^{\circ} \mathrm{C}$ に置くと， この分布は不均一になるが， これは低温にさらされたことによって一部の脂質がゲル 相に変化し, 液晶相と混在する相分離が起こり, タンパ ク質がゲル相から排除され，液晶相へ移行したためと考 えられる。

このように , バクテリアの細胞表面は外界との接点に あるため, 周囲の環境に敏感に影響を受けて変化する。 乥して兴のことが, バクテリア自身の環境ストレスによ る損傷や耐性を左右することにもなる。

3. ストレスを受けたバクテリアの細胞表面の 損傷と修復

殺菌や静菌処理によってバクテリアはストレスにさら されるが, 彼らは, 本質的に他の生物にも備わる巧妙な 応答機構によって, ストレスによる損傷や抑制から回復 や適応，耐性化を起こすことがわかってきている (Fig. 4)。兰れでは, 大腸菌を加熱処理するとどんなことが起 こるのかについて述べよう。

大腸菌を 50 〜 $55^{\circ} \mathrm{C}$ で加熱して位相差顕微鏡で見る と，外側に風船状に膨らんだブレッブ構造が現れた7”。 これは, 超薄切片の電子顕微鏡写真では, 多重層の膜で 覆われたもので, 細胞分裂面や細胞の端（極）の部分に 


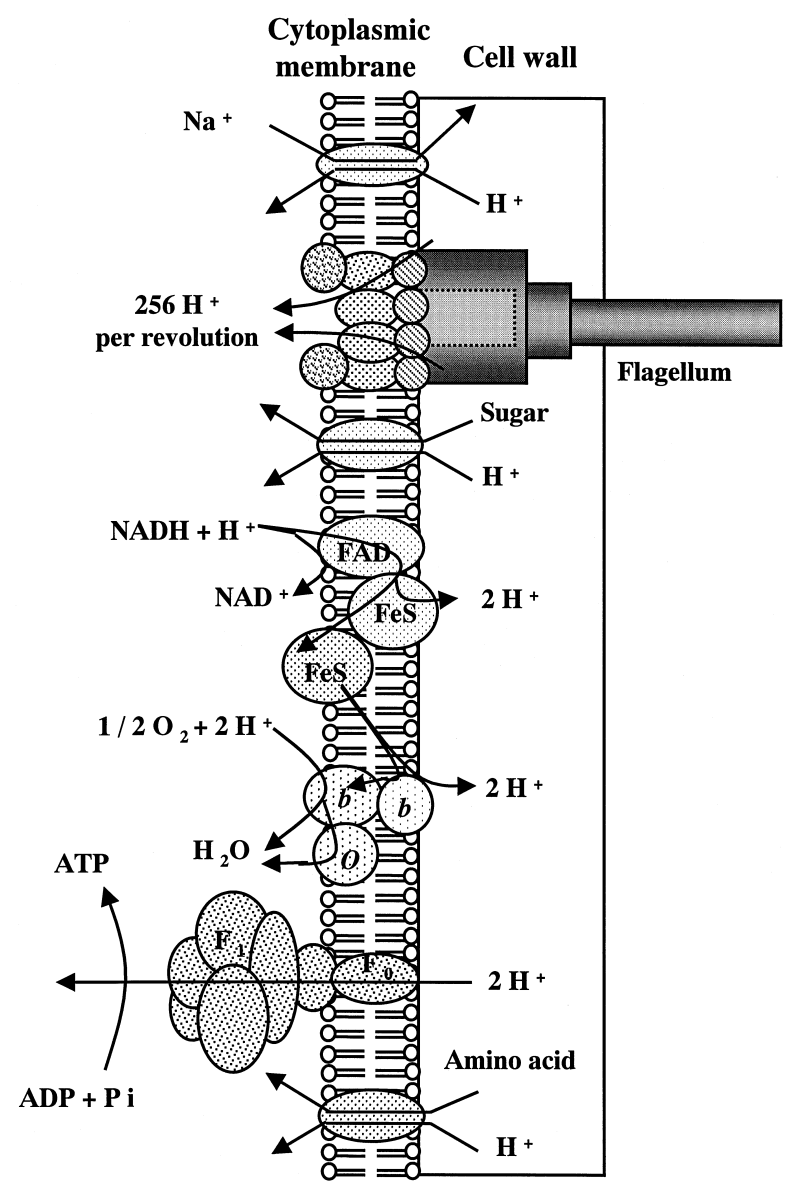

Fig. 2 Structure and functions of the cell membrane of E. coli.

多く見られた $(\text { Fig. 5 })^{7)}$ 。著者らはこのブレッブが遊離 した膜胞を超遠心分離によって集め, 兴の性質を調べた 結果, 密度は外膜と細胞質膜との間の值 $\left(1.21 \mathrm{~g} / \mathrm{cm}^{3}\right)$ をとり，外膜特有のリポ多糖体が存在するものの脂質の 割合が多く, 膜タンパク質が少ないことがわかった。ド デシル硫酸ナトリウム存在下でのポリアクリルアミド電 気泳動法によって膜タンパク質の分離パターンを見たと ころ, 膜胞に含まれるタンパク質は外膜由来であると推 察された。また, 酵素分析の結果から, 細胞内部に局在 する酵素は漏洩しておらず，外膜と細胞質膜との間のぺ リプラズム空間に局在する酵素が遊離したことから，こ の膜胞 , つまりブレッブは, 外膜か断片化しお光らく内 側のムレインと相互作用しているタンパク質などを残し た状態で形成され，弚の後さらに膜胞となって遊離する ものと推察された ${ }^{7,8)}$ 。この過程を表す模式图を Fig. 6 に示す。

このような表面の変化は細胞にどんな変化をもたらす だろうか?まず，n-へキサデカンとの混合によって水相 から消失する細胞数を測定する Rosenberg らの方法 ${ }^{9} に$ より，大腸菌の細胞表面の踈水度を調べたところ，表面 がより踈水性となることがわかっだ)。また，不透過性

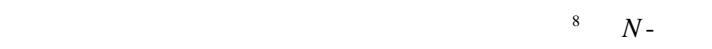
ニルナフチルアミン ${ }^{11}$ が細胞へ透過できるようになっ た。さらに, 大腸菌には阻害作用が小さい疎水性の比較 的高い抗生物質や抗菌化合物に対する感受性が増大し た

これらの事象に連動して, リン脂質分解酢素であるフ オスフォリパーゼCを細胞外から加えて処理すると， 未加熱細胞にはほとんど作用しないが, 加熱細胞の細胞 膜中のリン脂質を顕著に分解することがわかった ${ }^{8)}$ 。上 の細胞表面疎水性の上昇は, 本来外膜の表面にはないは ずのリン脂質が , 先のブレッブ形成と光の後の膜胞化遊 離によって出現したためであろうと推察される(Fig. 6)。 そとてさらに, このことが, 大腸菌の外膜を透過しにく 


\section{$37^{\circ} \mathrm{C}$}
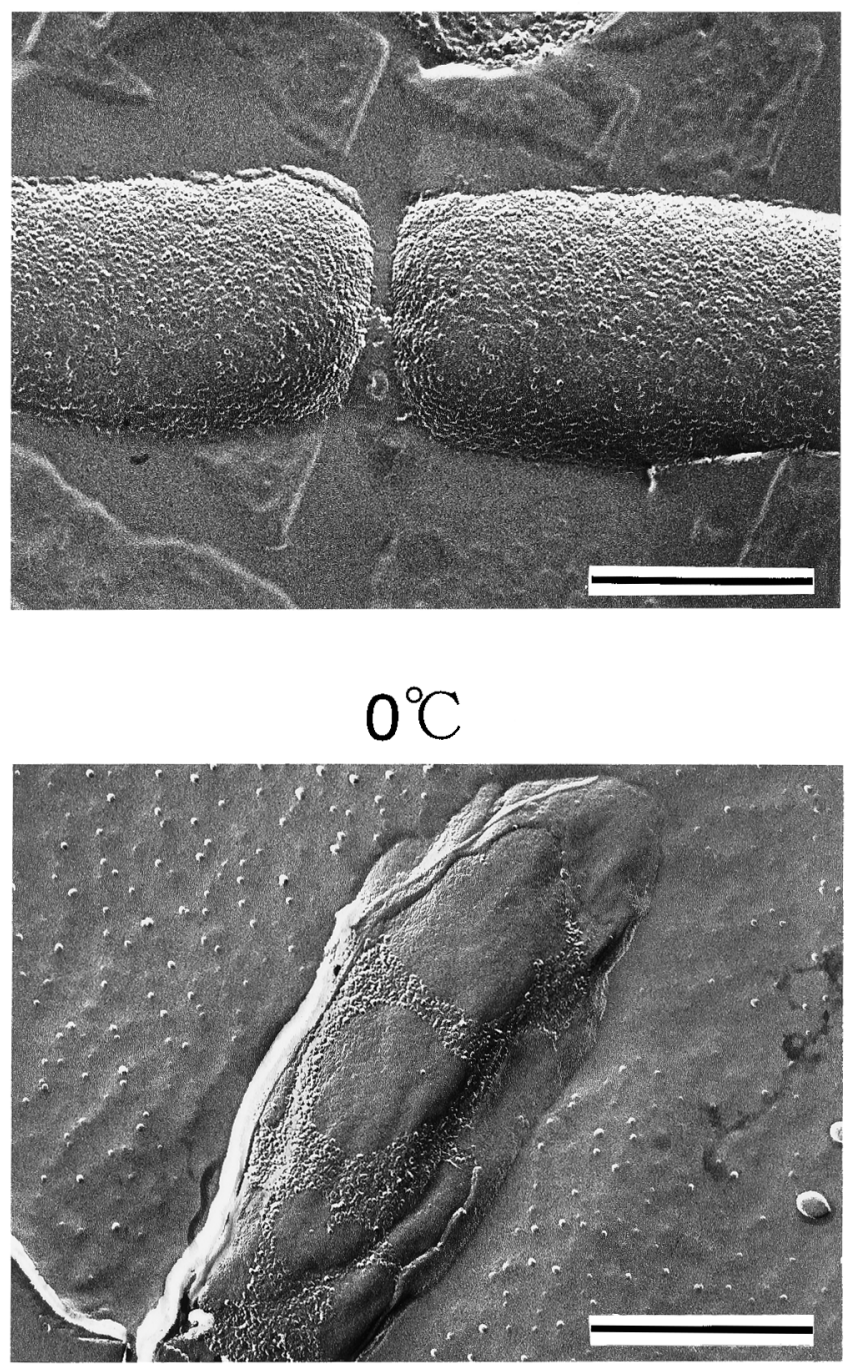

Fig. 3 Electron micrographs of freeze-fractured cell surface of E. coli cells grown at $37^{\circ} \mathrm{C}$ and then kept at 37 or $0{ }^{\circ} \mathrm{C}^{6)}$. Bar, $0.5 \mu \mathrm{m}$.

い踈水性の化合物や色素の透過を可能とし，光れらの阻 害作用に対して細胞を感受性にするものと推察される。

以上の結果を総合的に考察すれば, Nikaido ${ }^{10)}$ がサル モネラ菌の外膜欠損株および金属キレート剂の EDTA 処理細胞について考察したように，加熱処理細胞につい ても Fig. 6 のような類似のモデルで説明できると考えら れる。

このような大腸菌の外膜損傷は加熱後の適当な液体培 地での保温により, 修復される。リポ多糖体は再合成さ $れ^{12)}$, 疎水性色素に対する透過性障壁機能が再増殖開始
までに次第に元に戻る ${ }^{11)}$ 。

一方，細胞質膜の熱損傷については，外膜のような劇 的な構造変化は認められないが, 機能的には多くの傷害 が発生しているものと推察される。たとえば, 電子伝達 系の障害, 基質輸送能の低下, ATPなど細胞質低分子 成分の漏洩などがあげられ，とくに酸素存在下での加熱 処理による呼吸系障害は正常時よりも活性酸素発生量の 増加をもたらし，二次的な細胞損傷を引き起こしている と考えられる11。

最近, 著者の研究室では, グラム陽性バクテリアの枯 
草菌を熱ショックや低温ショックにさらすと, DNAの 切断が起こることを確認し，これが細胞表面に存在する デオキシリボヌクレアーゼである YokF が細胞膜から脱 離し，細胞質に移行して DNA を攻撃することを明らか にした ${ }^{14)}$ 。また，枯草菌は低温ショックによって自己溶 菌を起こすが, これは自己の細胞がもつ細胞壁分解酵素 であるオートリシンが脱制御されて活性化するためであ り，この活性化にやはり細胞膜か関与していることを示 唆している ${ }^{15)}$ 。

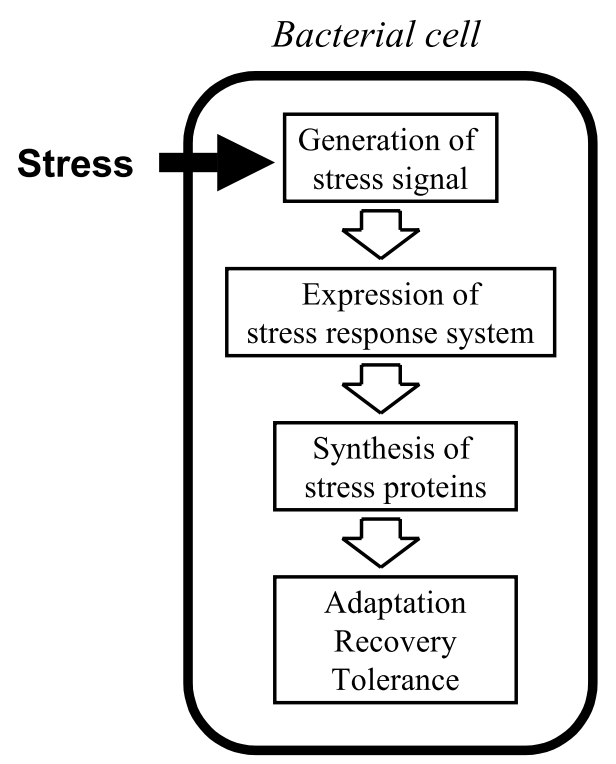

Fig. 4 Outline of stress response in bacterial cell.
4 . バクテリアの熱耐性における細胞表面の関 与と熱ストレス応答

以上のような細胞表面の損傷は, 細胞自身の生存性に 直接影響する可能性も考えられるが, 加熱の場合は細胞 内のさまざまな部位が損傷を受けており，どの傷害が決 定的に細胞死をもたらすのかよくわかっていない。しか し, 著者ら ${ }^{16)}$ は, 細胞の熱耐性に細胞表面が深く関わっ ていることを示す 1 つの例を報告している。

大腸菌細胞を $37^{\circ} \mathrm{C} て ゙$ 生育させ, 集菌洗浄後, 適当な 緩衝液中にしばらく予備保温してから $50^{\circ} \mathrm{C}$ 以上の温度 に加熱処理した場合, 弚の後の死滅は予備保温温度に依 存した。 $0^{\circ} \mathrm{C}$ から加熱すると， $37^{\circ} \mathrm{C}$ からのときに比べ て加熱中の死滅速度が大であった (Fig. 7 $)^{16)} 。 0^{\circ} \mathrm{C}$ と 37 ${ }^{\circ} \mathrm{C}$ の間の温度についても検討した結果 , この耐熱性の樣 相は細胞膜のゲル-液晶相転移, 相分離の挙動に一致す ることがわかった ${ }^{16)}$ 。先 (Fig. 3) に示したように, 37 ${ }^{\circ} \mathrm{C}$ に置いた細胞の脂質は液晶相にあり，比較的熱恧性で ある。相分離を起こし始める温度 $\left(T_{\mathrm{c}}\right.$, ここでは約 20 $\left.{ }^{\circ} \mathrm{C}\right)$ 以下では次第にゲル相の割合が増え, 熱処理に弱く なると推測される。この作業仮説は低温の $15^{\circ} \mathrm{C}$ で生育 させておいた細胞および不飽和脂肪酸要求変異株を用い て細胞膜の流動性を変化させ， $T_{\mathrm{c}}$ を変化させた実験か らも支持された ${ }^{16)}$ 。この仮説の基本的な概要を Fig. 8 に 示す。

熱に対するバクテリアの応答として, 上述の損傷修復 を紹介したが, 近年, 高温での特有の遺伝子発現機構が 関与するいわゆる熱ショック応答システムが明らかにな ってきている。DNA 上の遺伝子は炎の遺伝暗号がRNA

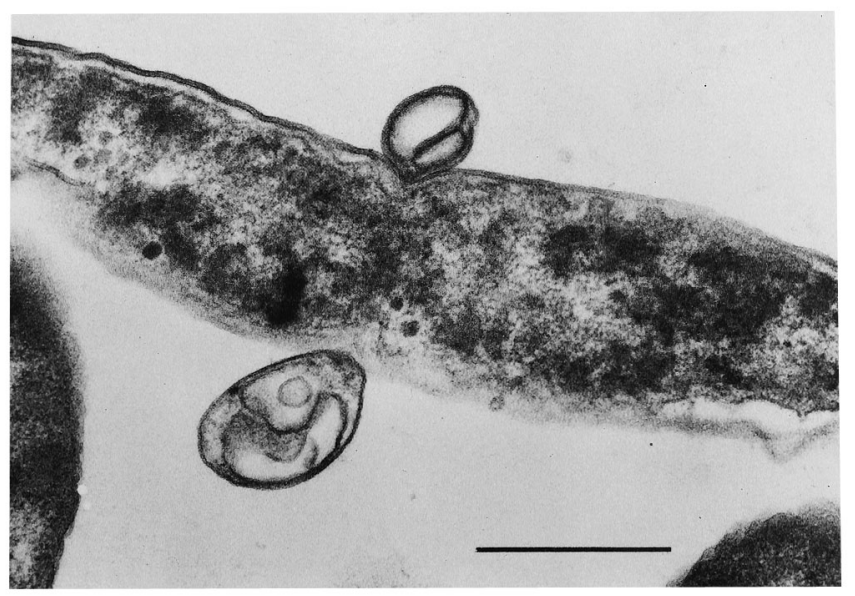

Fig. 5 An electron micrograph of an ultra-thin section of blebs produced on a heated cell of $E$. coli $^{7)}$. Bar, $0.5 \mu \mathrm{m}$. 


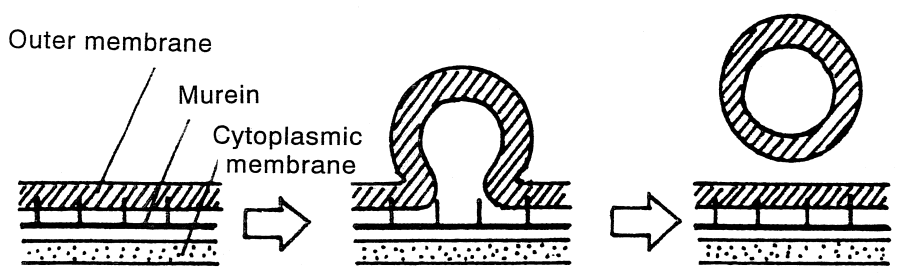

Hydrophobic compound
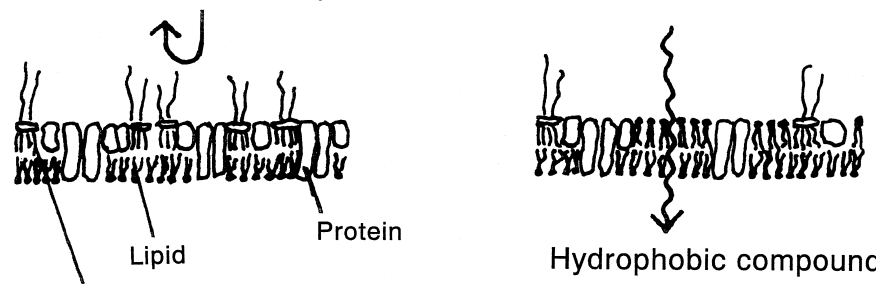

Lipoplysaccharide

Fig. 6 A model for blebbing and vesiculation of the outer membrane of a heated cell of $E$. coli $^{1}$.

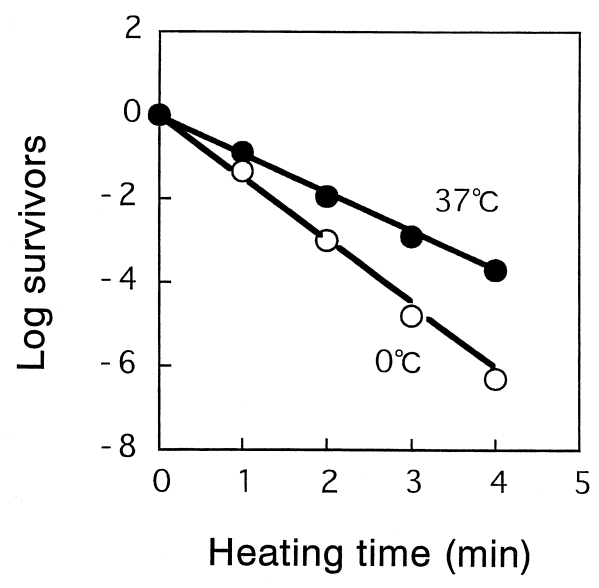

Fig. 7 Effect of preincubation temperature on the thermal death of $E$. coli heated at $50{ }^{\circ} \mathrm{C}^{16)}$.

合成酵素 (RNA ポリメラーゼ) によって伝令 RNA (mRNA) に転写され，さらにリボソームというタンパ ク質製造工場で翻訳されてさまざまな機能をもつタンパ ク質が合成される。高温ではタンパク質の変性が起こる ので, 弚れを防止・再生あるいは分解する機能をもつも のが多くを占める熱ショックタンパク質 (HSP) 群が, 光れ光れの遺伝子から作られる。大腸菌では，これらの 遺伝子の発現を RNA 合成酵素の 1 ユニットであるシグ マ因子の $\sigma^{32}$ という調節タンパク質が一括して制御して おり ${ }^{17)}$, これら発現してくる HSP は細胞質内で機能す る (Fig.9)。

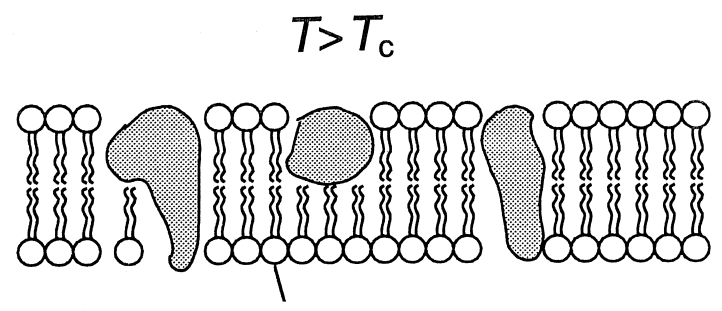

Liquid crystalline phase

$$
T<T_{\mathrm{c}}
$$

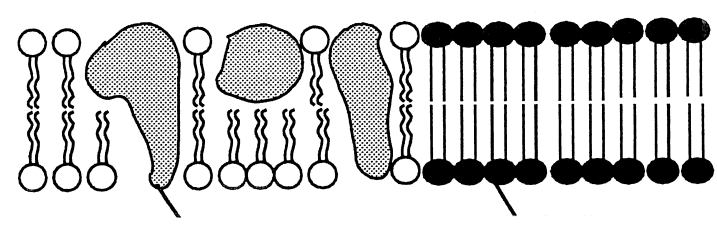

Protein

Gel phase

Fig. 8 A proposed model for the preincubation effect on the heat resistance of E. coli.

さらに弚の後, 細胞膜を含む細胞表面で働く第 2 の HSP 群が存在することが明らかにされた ${ }^{18)}$ 。この応答で は別のシグマ因子である $\sigma^{24}\left(\sigma^{\mathrm{E}}\right)$ がこの一群のタンパ ク質の遺伝子発現を調節し, 主に細胞表面でのタンパク 質の構造形成の誤りを処理するタンパク質群が誘導合成 


\section{Heat stress}

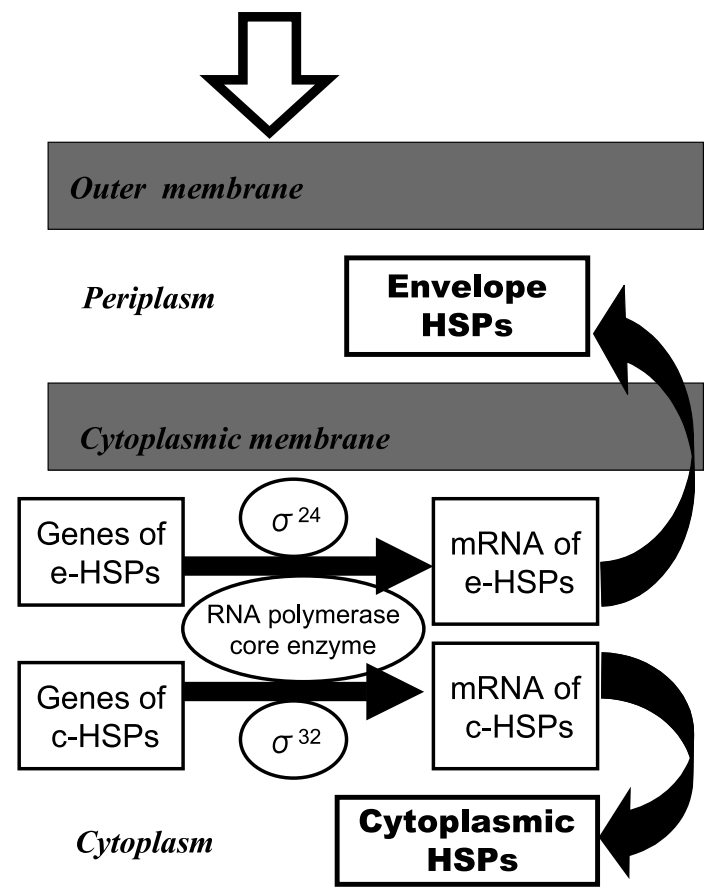

Fig. 9 Heat shock responses in E. coli.

される。

\section{5.おわりに}

細胞表面は , バクテリア細胞の種々のストレスに対す る耐性や損傷に重大な影響を及ぼす。ここで示した熱ス トレス以外にも，薬剂ストレスでは薬斉の透過や排出に 関係し , 超高圧や放射線ストレスにおいても細胞表面が 顕著に関わっていることが知られている。これらストレ スに対して , バクテリアは光れ光れ特有のストレス遺伝 子を活発に発現させ, 光の産物であるストレスタンパク 質を合成し，光の働きによって細胞のストレス防御機能 を発揮する。このようなシステムは, 人間をはじめ, さ まざまな生物に本来共通のものである。細胞表面は外界
情報との交信の場であることから，複杂隹な生理機能が集 積しており, 光の傷害は細胞の生命に甚大な影響を及ぼ すだろう。有害バクテリアの有効な制御のためには, 彼 らのストレス防御戦略システムを知る必要があるが, と くに細胞表面のストレス防御機構の解明は, 将来の新し いバクテリア制御法の開発をもたらす可能性が期待でき る。

\section{文献}

1) 土戶哲明 : 日本防菌防徵学会誌 18, 75 (1990).

2) 土戶哲明 “熱殺菌のテクノロジー”, 高野光男 , 土 戶哲朗編（サイエンスフォーラム，1997) p. 42.

3) 土戶哲明 : 凍結及び乾燥研究会会誌 39, 61 (1993).

4) 土戶哲明 : 日本食品科学工学会誌 46, 1 (1999).

5) F.C. Neidhardt, J.L. Ingraham and M. Schaechter: "Physiology of the Bacterial Cell" (Sinauer, Sunderland, 1990).

6) 土戶哲明, 藤川清三 : 未発表.

7) N. Katsui, T. Tsuchido, R. Hiramatsu, S. Fujikawa, M. Takano and I. Shibasaki: J. Bacteriol. 151, 1523 (1982).

8) T. Tsuchido, N. Katsui, A. Takeuchi, M. Takano and I. Shibasaki: Appl. Environ. Microbiol. 50, 298 (1985).

9) M. Rosenberg, D. Gitmocl and E. Rosenberg: FEMS Microbiol. Lett. 9, 29 (1980).

10) H. Nikaido and M. Vaara: Microbiol. Rev. 49, 1 (1985).

11) T. Tsuchido, I. Aoki and M. Takano: J. Gen. Microbiol. 135, 1941 (1989).

12) T. Tsuchido, A. Takeuchi and M. Takano: J. Appl. Bacteriol. 73, 531 (1992).

13) T. Tsuchido and M. Takano: Antimicrob. Ag. Chemother. 32, 1680 (1988).

14) J. J. Sakamoto, K. Minami and T. Tsuchido: submitted.

15) T. Tsuchido, T. Nishino, Y. Kato and M. Takano: Biosci. Biotech. Biochem. 59, 1636 (1995).

16) N. Katsui, T. Tsuchido, M. Takano and I. Shibasaki: J. Gen. Microbiol. 122, 357 (1981).

17) T. Yura, M. Kanemori and M.T. Morita: "Bacterial Stress Responses", ed. by G. Storz and R. Hengge-Aronis (ASM Press, Washington, D.C., 2000) p.3.

18) T.L. Raivio and T.J. Silhavy: "Bacterial Stress Responses", ed. by G. Storz and R. Hengge-Aronis (ASM Press, Washington, D.C., 2000) p. 19. 